\begin{tabular}{cc|c}
\hline Tar. Bil. Der. & Journal of Agricultural Sciences \\
& $\begin{array}{c}\text { Dergi web sayfası: } \\
\text { www.agri.ankara.edu.tr/dergi }\end{array}$ & Journal homepage: \\
& www.agri.ankara.edu.tr/journal
\end{tabular}

\title{
Pre-harvest Application of ReTain (Aminoethoxyvinylglycine, AVG) Influences Pre-harvest Drop and Fruit Quality of 'Williams' Pears
}

\author{
Sinan BUTAR ${ }^{a}$, Melike ÇETINBAŞ ${ }^{a}$ \\ ${ }^{\text {a } F r u i t ~ R e s e a r c h ~ I n s t i t u t e, ~ 32500, ~ E g ̆ i r d i r, ~ I s p a r t a, ~ T U R K E Y ~}$
}

\section{ARTICLE INFO}

Research Article

DOI: 10.15832 ankutbd.447704

Corresponding Author: Sinan BUTAR, E-mail: sinanbutar@gmail.com, Tel: +90 (246) 3132420

Received: 18 July 2014, Received in Revised Form: 23 March 2015, Accepted: 19 February 2016

\begin{abstract}
'Williams' is the highly quality pear cultivar mostly produced in the Eğirdir region of Turkey. ReTain (15\% aminoethoxyvinilglycine, AVG) is a plant growth regulator used to control pre-harvest drop and increase fruit weight and firmness. The objective of this study was to determine the responses of AVG treatments on the preharvest drop and fruit quality of 'Williams' pear. Pear trees of the cultivar 'Williams' were sprayed 30, 21 and 7 days before commercial harvest (DBH) with AVG, at doses of 100,125 and $150 \mathrm{mg} \mathrm{L}^{-1}$, and assessed for pre-harvest drop, yield, maturity, delay in harvest, fruit quality, ethylene production and respiration rate at the harvest time. Fruit samples were analyzed for fruit quality parameters which are: fruit width, fruit weight, soluble solids content (SSC), titratable acidity (TA), fruit firmness, fruit colour, fruit macro and micro elements content. Maturation of the 30 and 21 DBH AVG-treated fruits were delayed 3-4 days compared to the 7 DBH AVG-treated and control groups. The pre-harvest drop decreased with all AVG applications by approximately $38-100 \%$ in comparison with the control group fruits. AVG treatments increased fruit size (7-10\%), fruit weight (26-41\%) and fruit firmness (2-16\%) of 'Williams' pear. AVG application reduce ethylene production and respiration rate and it was found that the applications enhance the ethylene production and respiration rate by approximately $(100 \%)$ compared to the control fruits on the harvest date. Results of this study indicated that $30 \mathrm{DBH}$ and $21 \mathrm{DBH}$ AVG-treatments at 100 $\mathrm{mg} \mathrm{L}^{-1}$ can be recommended for 'Williams' pear cultivar on both pre-harvest fruit drop, as well as in harvest date and fruit quality.
\end{abstract}

Keywords: Pear; Harvest time; Fruit quality; 'Williams'; Pre-harvest drop; AVG

\section{Hasat Öncesi ReTain (Aminoethoxyvinylglycine, AVG) Uygulamalarının 'Williams' Armut Çeşidinde Hasat Önü Dökümü ve Meyve Kalitesi Üzerine Etkileri}

\section{ESER BİLGISİ}

Araştırma Makalesi

Sorumlu Yazar: Sinan BUTAR, E-posta: sinanbutar@gmail.com, Tel: +90 (246) 3132420

Geliş Tarihi: 18 Temmuz 2014, Düzeltmelerin Gelişi: 23 Mart 2015, Kabul: 19 Şubat 2016 


\begin{abstract}
ÖZET
'Williams' armudu Türkiye'nin Eğirdir bölgesinde üretimi fazla olan kaliteli bir çeşittir. ReTain (\% 15 aminoetoksivinilglisin, AVG), hasat önü meyve dökümünün kontrolünde, meyve ağırlığı ve meyve eti sertliğinin artırılmasında kullanılmakta olan bir bitki büyüme düzenleyicisidir. Bu çalışma, 'Williams' armudunda hasat önü meyve dökümü ve meyve kalitesi üzerine AVG uygulamalarının etkilerini incelemek amacıyla yürütülmüştür. Bu amaçla, tahmini hasat zamanından (THZ) 30, 21 ve 7 gün önce 0,100, 125, $150 \mathrm{mg} \mathrm{L}^{-1}$ dozlarında AVG armut ağaçlarına püskürtme şeklinde uygulanmıştır. Hasat önü meyve dökümü, verim, olgunluk, hasat tarihinin gecikmesi, meyve kalitesi, meyvelerin etilen üretimi ve solunum hızları hasat zamanında incelenmiştir. Hasat edilen meyvelerin kalite parametreleri olarak meyve çap1, meyve ağırlığ 1 , meyve eti sertliği, meyve rengi, suda çözünebilir kuru madde, titre edilebilir asitlik ve meyvelerde makro-mikro elementler analiz edilmiştir. THZ 30 ve 21 önce uygulanan AVG uygulamaları ile meyve olgunluğu kontrol grubuna ve THZ 7 önce uygulanan AVG uygulamalarına göre 3-4 gün gecikmiştir. AVG uygulamaları ile hasat önü meyve dökümü \% 38-100 arasında oldukça azalmış olup meyve boyutu (\% 7-10), ağırlığg (\% 26-41) ve meyve sertliği de (\% 2-16) artmıştır. AVG uygulamaları meyvelerdeki etilen üretimi ve solunum hızını da kontrol grubuna göre neredeyse \% 100 yavaşlatmıştır. Sonuç olarak, 'Williams' armut çeşidinde, gerek hasat önü meyve dökümü, gerekse hasat zamanı ve meyve kalitesi bakımından THZ 30 ve 21 gün önceki $100 \mathrm{mg} \mathrm{L}^{-1}$ 'lik uygulamaların en uygun uygulamalar olduğu tavsiye edilmektedir.
\end{abstract}

Anahtar Kelimeler: Armut; Hasat zamanı; Meyve kalitesi; 'Williams’; Hasat önü döküm; AVG

(C) Ankara Üniversitesi Ziraat Fakültesi

\section{Introduction}

Pre-harvest drop of pears happens because the fruit developed an immaturity, and in most cases, economic damage usually causes a serious economic loss. A good quality 'Williams' (Bartlett) pear should have a fruit medium largelarge conical neck; the middle part is wide. Light green peel, a thin, hollow stem with rust coloured surroundings, eating death are yellow. The flesh is white, fine-textured, like butter type, very juicy, sweet and aromatic and the quality is excellent. Suppressing ethylene production in 'Williams' pears may increase yields by reducing premature fruit abscission, and indirectly increase fruit size by delaying harvest of slower-maturing fruit. 'Williams' growers often use the synthetic auxin, naphthaleneacetic acid (NAA), which can compress pre-harvest abscission, however can also result in fruit softening. Reducing fruit ethylene production may reduce the incidence of premature ripening on the tree, enhance the storage life, and reduce the rate of ripening of 'Williams' pears (Clayton et al 2000). AVG (aminoethoxyvinylglycine) inhibit ethylene biosynthesis pathway (Kim et al 2004), and can thus compress ethylene production in many climacteric fruits (Yang et al 1982). Pre and post-harvest applications of AVG have been evaluated as a tool to enhance production and quality attributes of climacteric fruits (Çetinbaş et al 2012). AVG delaying the harvest of fruits result in them being larger and thus increases the yield. Delay in harvesting may convenience flexibility in labor, packaging and fruit processing, storage and marketing (Amarante et al 2005).

Pre and post-harvest treatments with AVG inhibited ethylene production and delayed harvesting of pears (Romani et al 1983) and peaches (Çetinbaş \& Koyuncu 2011). With the 'Barlett' pear, preharvest AVG treatments either 14 or 7 days before harvest did not affect ethylene production at harvest, but delayed changes in skin colour, softening and starch content (Clayton et al 2000). Andreotti et al (2004) found that pre-harvest treatment with AVG at $125 \mathrm{mg} \mathrm{L}^{-1}$ delayed maturation of 'Abbe Fetel' pears by 5 to 15 days.

Therefore, this study was conducted to determine the effects of AVG applications different doses, sprayed 30, 21 and 7 days before commercial harvest, on pre-harvest drop, fruit maturity and fruit quality of 'Williams' pears. 


\section{Material and Methods}

\subsection{Plant material}

The trials were conducted at the Fruit Research Station of Eğirdir, Turkey in 2011-2012. Uniform 10-years-old pear trees of the cv. 'Williams', grafted on Quince C rootstock and spaced at $1.5 \times 4 \mathrm{~m}$ were used. The experiment was designed in completely randomized blocks of 4 replications, using a single tree for each treatment.

\subsection{AVG treatments}

ReTain was (Valent BioScience Corporation) sprayed at 0 (water+surfactant), 100, 125, $150 \mathrm{mg}$ $\mathrm{L}^{-1}$ plus $1 \%\left(\mathrm{v} \mathrm{v}^{-1}\right)$ Tween 20 as a surfactant onto fruits and leaves around the fruits until runoff. The spraying was performed with a hand pump sprayer at 7, 21 and 30 days before (DBH) in 2011 and 2012. Application time and dose of AVG were determined according to Çetinbaş \& Koyuncu (2011).

\subsection{Fruit maturity and harvest determination}

When the pear fruits firmness were 80 to $89 \mathrm{~N}$, fruits were harvested at a commercial stage of maturity. AVG-treated fruits and untreated fruits were harvested separately and picked into specially designated bins. After each harvest pick, fruit was transported to the Pomology Laboratory of Fruit Research Station. Fruits were harvested 2 times from 21 to 24 September 2011 (I. year) and from 19 to 23 September 2012 (II. year).

\subsection{Yield and pre-harvest drop determination}

The yield was determined at harvest as per tree $\mathrm{kg}$ in the first and second year. In order to determine the pre-harvest drop rate, existing fruits on each tree were identified one month before commercial harvest (DBH) and then, twice every week. Fallen fruits were counted under the trees in the first and second year. The results were expressed as percent $(\%)$.

\subsection{Fruit quality determination}

Fruit width, fruit weight and fruit firmness: The measurement of twenty fruits were determined using digital calipers for fruit width (mm). Fruit weight $(\mathrm{g})$ was measured by a digital scales sensitive to $0.01 \mathrm{~g}$. Fruit firmness (Newton) was measured by using a texture analyser (Lloyd Instruments LF Plus) incorporating an $8 \mathrm{~mm}$ diameter probe.

Soluble solid content (SSC) and titratable acidity (TA): The rates of SSC were measured by a digital refractometer (Palette PR-32 Atago). TA by manual titration with $0.1 \mathrm{~N} \mathrm{NaOH}$ and expressed as $\mathrm{g}$ malic acid $100 \mathrm{~g}^{-1}$.

Fruit colour: The colour of the fruit was measured with a colorimeter (Minolta CR-300). Peel colours were evaluated as CIE L*, $a^{*}, b^{*}, C^{*}, h^{\circ}$.

\subsection{Respiration rate and ethylene production determination}

Ethylene production $\left(\mu \mathrm{L} \mathrm{kg}^{-1} \mathrm{~h}^{-1}\right)$ and respiration rate $\left(\mu \mathrm{L} \mathrm{kg}^{-1} \mathrm{~h}^{-1}\right)$ were defined pear of close to the jar after 1 day. Measurement of respiratory rate was done with gas analizator. Ethylene production was determined by using gas chromatography with a flame ionization detector (Gunes et al 2001).

Fruit mineral composition determination: The mineral contents of the fruit samples were analyzed. Samples were washed thoroughly with fountain water, dilute acid $(0.2 \mathrm{~N} \mathrm{HCl})$ and distilled water to remove surface residues, and dried at $70 \pm 5{ }^{\circ} \mathrm{C}$. Dried samples were ground with a stainless-steel mill for analytic procedures. The $\mathrm{P}, \mathrm{K}, \mathrm{Ca}, \mathrm{Mg}, \mathrm{Fe}$, $\mathrm{Cu}, \mathrm{Mn}, \mathrm{Zn}$ and $\mathrm{B}$ concentrations were determined by Inductively Coupled Plasma Atomic Emission spectrometry (Perkin Elmer Optima, Germany) method. Nitrogen was determined by the Kjeldahl (Gerhardt, Germany) procedure. The resulting data was expressed as a percentage of dry tissue (\%) for $\mathrm{N}, \mathrm{P}, \mathrm{K}, \mathrm{Ca}, \mathrm{Mg}$, whereas $\mathrm{Fe}, \mathrm{Cu}, \mathrm{Mn}, \mathrm{Zn}$ and $\mathrm{B}$ were recorded as milligrams per kilogram of dry fruit.

\subsection{Statistical analysis of results}

The experiment was based as a completely randomized blocking pattern as four replications and was assigned as one tree for each replication. The data was statistically analyzed (Duncan's multiple 
range test at $\mathrm{P} \leq 0.05$ ) using SPSS (V.18; Statistical software, SPSS. Inc., USA) software program. Fruit colours and fruit mineral compositons were done during two years and the data presented here are the mean results of these years.

\section{Results and Discussion}

\subsection{Fruit maturity and harvest}

Considering fruit firmness and colour, 'Williams' pear harvests of all treatments were performed at harvest maturation in our study. The $30 \mathrm{DBH}$ and $21 \mathrm{DBH}$ AVG treatments were harvested later than control and 7 DBH AVG-treated fruits (In the first and second year). Control and 7 DBH AVG-treated fruits were harvested on the $21^{\text {st }}$ September while 30 and $21 \mathrm{DBH}$ AVG applied fruits were harvested on the 24th September (in 2011). In 2012, fruits were harvested on the $19^{\text {th }}$ September (control and 7 DBH AVG-treated fruits) and 23 September (30 and $21 \mathrm{DBH}$ AVG-treated fruits). Consequently, it was observed AVG treatments delayed harvest time by 3 days. It was reported in many studies done with pears and apples that AVG applications delay harvest time showing similarities with our findings (Clayton et al 2000; Schupp \& Greene 2004; Greene 2006; Petri et al 2006; Rath et al 2006; WookJae et al 2006; Kang et al 2007; Whale et al 2008). Phan-Thien et al (2004) showed the effect of $125 \mathrm{mg} \mathrm{L}^{-1}$ of AVG sprayed onto 'Gala' and 'Pink Lady' apples in the first 5 to 12 days delayed ripening by 5 to 7 days. In a study conducted in a commercial orchard of 'Arctic Snow' nectarines, application of $125 \mathrm{mg} \mathrm{L}^{-1}$ AVG 7 days before anticipated first harvest gave a 2.75 day harvest delay based on standard commercial maturity criteria (Rath \& Prentice 2004).

\subsection{Yield and pre-harvest drop}

In both years, AVG treatments increased fruit yield. AVG concentrations $x$ application times interaction on the yield was found to be statistically significant $(\mathrm{P} \leq 0.05)$ in 2011. In the second year (2012), AVG had not significant effects on yield (Table 1). The highest yield was found in the plot submitted to 30 DBH-100 mg L-1 AVG treatment (in the first year).
In both years, as illustrated in Table 1, pre-harvest fruit drop was influenced significantly by AVG concentrations and application times $(\mathrm{P} \leq 0.05)$. The highest pre-harvest fruit drop was observed in 7 DBH-control fruits (in 2011). In 2012, fruits of the $21 \mathrm{DBH}$-control were higher than the others. In both years, the pre-harvest drop was not observed after treatment with $150 \mathrm{mg} \mathrm{L}^{-1} \mathrm{AVG}$ concentration at 21 DBH (Table 1). Karaçalı (2009) reported that pre harvest drop depends on the plant species and its variety. Hot or cold weather conditions, late time fertilization with high nitrogen content, drought and high soil water level, low boron and magnesium levels in the soil increase pre harvest drop ratio. Cultural practices are not enough to prevent pre harvest drop. Plant growth regulators must be used to prevent pre harvest drop. In our study, AVG treatments were used in an orchard which has regular cultural practice and AVG treatments were used to control pre harvest drop. The effects of AVG applications on pre-harvest fruit drop and yield are highly significant in our research. It was determined that pre-harvest fruit drop was reduced by AVG treatments. Pre-harvest fruit drop has never been detected after 30 DBH-150 mg L $\mathrm{m}^{-1}$ and all doses of $21 \mathrm{DBH}$ applications. Accordingly, it was found that the aforementioned applications enhance the fruit yield as compared to the other applications. The percentage of pre-harvest fruit drop decreased in parallel with the increase in treatment doses. In one of his studies regarding AVG's effectiveness on pre-harvest apple drop control, Greene (2006) stated that increase in AVG is directly correlated with its concentration, meaning increase in dose. Greene (2006) also reported that the most appropriate and effective time to apply the treatment is $2-3$ weeks before the estimated harvest. It was revealed in our study, in line with the results of many researchers, that $\mathrm{AVG}$ prevents or reduces the pre-harvest fruit drop (Greene 2006; Petri et al 2006; Rath et al 2006; WookJae et al 2006; Kang et al 2007; Whale et al 2008). These results are considered to be important for the prevention or reduction of pre-harvested losses approximately $10 \%$ of pre-harvest drop. We also believe the results affect pear growers favourably on economic aspects. 
Table 1- The effect of AVG treatments on yield and pre-harvest fruit drop in the 'Williams' pear, 2011 and 2012

Çizelge 1- AVG uygulamalarının 'Williams'armudunda verim ve hasat önü meyve dökümüne etkisi, 2011 ve 2012

\begin{tabular}{|c|c|c|c|c|c|}
\hline \multirow{2}{*}{ Application time ${ }^{I}$} & \multirow{2}{*}{$\begin{array}{l}\text { AVG concentrations } \\
\left(m g L^{-1}\right)\end{array}$} & \multicolumn{2}{|c|}{ Yield (kg tree $\left.{ }^{-1}\right)$} & \multicolumn{2}{|c|}{ Pre-harvest drop (\%) } \\
\hline & & 2011 & 2012 & 2011 & 2012 \\
\hline \multirow{4}{*}{$30 \mathrm{~d}$} & 0 & $8.30 \mathrm{a}-\mathrm{c}$ & 9.65 & $24.92 \mathrm{a}$ & $8.52 \mathrm{~b}$ \\
\hline & 100 & $12.46 \mathrm{a}$ & 16.81 & $0.00 \mathrm{~b}$ & $2.51 \mathrm{c}$ \\
\hline & 125 & $9.07 \mathrm{a}-\mathrm{c}$ & 16.06 & $0.00 \mathrm{~b}$ & $0.79 \mathrm{c}$ \\
\hline & 150 & $7.74 \mathrm{bc}$ & 13.05 & $2.54 \mathrm{~b}$ & $0.00 \mathrm{c}$ \\
\hline \multirow{4}{*}{$21 \mathrm{~d}$} & 0 & $7.53 \mathrm{bc}$ & 11.71 & $25.60 \mathrm{a}$ & $16.43 \mathrm{a}$ \\
\hline & 100 & $11.18 \mathrm{ab}$ & 14.04 & $0.00 \mathrm{~b}$ & $0.00 \mathrm{c}$ \\
\hline & 125 & $6.69 \mathrm{bc}$ & 11.84 & $4.25 \mathrm{~b}$ & $0.00 \mathrm{c}$ \\
\hline & 150 & $7.02 \mathrm{bc}$ & 15.71 & $0.00 \mathrm{~b}$ & $0.00 \mathrm{c}$ \\
\hline \multirow{4}{*}{$7 \mathrm{~d}$} & 0 & $4.42 \mathrm{c}$ & 12.62 & $26.90 \mathrm{a}$ & $13.12 \mathrm{a}$ \\
\hline & 100 & $5.35 \mathrm{c}$ & 13.24 & $6.06 \mathrm{~b}$ & $1.96 \mathrm{c}$ \\
\hline & 125 & $6.63 \mathrm{bc}$ & 13.68 & $3.49 \mathrm{~b}$ & $7.90 \mathrm{~b}$ \\
\hline & 150 & $7.73 \mathrm{bc}$ & 14.32 & $4.75 \mathrm{~b}$ & $0.84 \mathrm{c}$ \\
\hline \multicolumn{6}{|l|}{ Time } \\
\hline 30 & & 9.39 & 12.82 & 6.87 & 2.96 \\
\hline 21 & & 8.10 & 12.62 & 7.46 & 13.12 \\
\hline \multirow[t]{6}{*}{7} & & 6.03 & 12.77 & 10.30 & 5.96 \\
\hline & AVG concentrations & & & & \\
\hline & 0 & 6.75 & 12.17 & 25.81 & 12.04 \\
\hline & 100 & 9.66 & 13.77 & 2.02 & 1.49 \\
\hline & 125 & 7.46 & 13.86 & 2.58 & 2.90 \\
\hline & 150 & 7.50 & 12.92 & 2.43 & 0.28 \\
\hline \multicolumn{6}{|l|}{ P values } \\
\hline Time $(\mathrm{T})$ & & 0.016 & 0.951 & 0.747 & 0.477 \\
\hline Concentrations $(\mathrm{C})$ & & 0.184 & 0.381 & 0.000 & 0.000 \\
\hline $\mathrm{T} \times \mathrm{C}$ & & 0.027 & 0.867 & 0.000 & 0.000 \\
\hline
\end{tabular}

${ }^{1}$, days before harvest (DBH); in each column, values followed by the same letter are not significantly different at $\mathrm{P} \leq 0.05$ level according to Duncan's multiple range test

\subsection{Fruit quality}

Fruit width, fruit weight and fruit flesh firmness: In both years, AVG applications significantly $(\mathrm{P} \leq 0.05)$ increased fruit width and weight in 'Williams' pear cultivar. The heaviest fruits were obtained from 21 DBH-100 mg L-1 (380.46 $\mathrm{g}$ in first year and $335.00 \mathrm{~g}$ in second year) AVG dose (Table 2). AVG applications increase 'Williams' pear fruit width and weight and it was found that the applications enhance the fruit width by approximately $7-10 \%$ and fruit weight by $26-41 \%$ in comparison with the control group fruits. Petri et al (2006) states AVG enhances fruit weights of 'Gala' and 'Fuji' apples as compared to the control group. Greene (2006) also expresses that AVG-applied fruits are generally bigger since it helps fruit remain on the tree for a longer time. In our study, the biggest pears were obtained from the application of 21 DBH-100 mg L-1 and 21 DBH-150 $\mathrm{mg} \mathrm{L}^{-1}$. Venburg et al (2008) stated that continuing research has extended and refined the use of AVG in apples and stone fruit. AVG's ripening and harvest delay effect have been investigated, examining the effect of harvest delay on fruit size and yield. When the untreated fruit and ReTain-treated fruit were 
harvested at the same stage of ripening, the fruit size in the ReTain treatment was larger due to the 7 days delay. In the ReTain treatments, the mass of small size fruit per tree $(<65 \mathrm{~mm})$ was reduced and the mass of larger size fruit per tree $(>65$ $\mathrm{mm})$ was increased. In addition, the overall yield was $11 \%$ greater treatment. In both years, AVG treatments had a significant influenced on fruit flesh firmness. In 2011, Fruit flesh firmness was affected significantly by AVG concentrations and application times $(\mathrm{P} \leq 0.05)$. In 2012, Fruit flesh firmness was influenced significantly by $\mathrm{AVG}$ concentrations $(\mathrm{P} \leq 0.05)$ (Table 2). In first year, the harder fruits were found after $21 \mathrm{DBH}-100 \mathrm{mg} \mathrm{L}^{-1}(88.72 \mathrm{~N})$ and $7 \mathrm{DBH}-100 \mathrm{mg} \mathrm{L}^{-1}(88.30 \mathrm{~N})$ AVG treatments.
However, the fruit firmness-increasing effect of AVG concentrations was more distinctive in the second year experiments. The $125 \mathrm{mg} \mathrm{L}^{-1} \mathrm{AVG}$ treatment determined the highest fruit firmness values (88.39 $\mathrm{N})$ at the harvest. This was followed by 100 and $150 \mathrm{mg} \mathrm{L}^{-1}$ AVG doses (Table 2). Similarly to our findings, the dose of $125 \mathrm{mg} \mathrm{L}^{-1}$ AVG enhanced the fruit firmness before the harvest time of 'Tsugaru' apples (WookJae et al 2006). Besides, it was stated that AVG application has favourable impact on fruit firmness of different apple types such as 'McIntosh', 'Spartan', 'Spencer' (Bramlage et al 1980), 'Gala' and 'Jonagold' (Wang \& Dilley 2001). In a study done with 'Bartlett' pear, Clayton et al (2000) states that AVG boosted fruit firmness. Keeping the pears

Table 2- The effect of AVG treatments fruit width, weight and flesh firmness in 'Williams' pear, 2011 and 2012 Çizelge 2- AVG uygulamalarının 'Williams' armudunda meyve çapına, ağırlı̆̆ına ve sertliğine etkisi, 2011 ve 2012

\begin{tabular}{|c|c|c|c|c|c|c|c|}
\hline \multirow[t]{2}{*}{ Application time ${ }^{I}$} & \multirow{2}{*}{$\begin{array}{l}\text { AVG concentrations } \\
\left(m g L^{-1}\right)\end{array}$} & \multicolumn{2}{|c|}{$\begin{array}{l}\text { Fruit width } \\
(\mathrm{mm})\end{array}$} & \multicolumn{2}{|c|}{$\begin{array}{l}\text { Fruit weight } \\
\text { (g) }\end{array}$} & \multicolumn{2}{|c|}{$\begin{array}{l}\text { Fruit flesh firmness } \\
(N)\end{array}$} \\
\hline & & 2011 & 2012 & 2011 & 2012 & 2011 & 2012 \\
\hline \multirow{4}{*}{$30 \mathrm{~d}$} & 0 & $70.73 \mathrm{f}$ & $74.20 \mathrm{~cd}$ & $189.13 \mathrm{f}$ & $226.33 \mathrm{e}$ & $78.04 \mathrm{c}$ & 84.71 \\
\hline & 100 & $78.07 \mathrm{c}$ & $82.94 \mathrm{ab}$ & $266.54 \mathrm{c}$ & $315.17 \mathrm{a}-\mathrm{c}$ & $82.12 \mathrm{a}-\mathrm{c}$ & 88.44 \\
\hline & 125 & $77.03 \mathrm{~cd}$ & $82.54 \mathrm{ab}$ & $252.28 \mathrm{~cd}$ & $314.00 \mathrm{a}-\mathrm{c}$ & $86.32 \mathrm{ab}$ & 89.25 \\
\hline & 150 & $74.04 \mathrm{e}$ & $77.17 \mathrm{~b}-\mathrm{d}$ & $217.23 \mathrm{e}$ & $257.67 \mathrm{c}-\mathrm{e}$ & $86.52 \mathrm{ab}$ & 90.12 \\
\hline \multirow{4}{*}{$21 \mathrm{~d}$} & 0 & $70.60 \mathrm{f}$ & $72.50 \mathrm{~cd}$ & $193.12 \mathrm{f}$ & $241.00 \mathrm{de}$ & $76.77 \mathrm{~cd}$ & 84.31 \\
\hline & 100 & $86.17 \mathrm{a}$ & $84.75 \mathrm{a}$ & $380.46 \mathrm{a}$ & $335.00 \mathrm{a}$ & $88.72 \mathrm{a}$ & 89.54 \\
\hline & 125 & $80.83 \mathrm{~b}$ & $84.29 \mathrm{ab}$ & $303.19 \mathrm{~b}$ & $326.67 \mathrm{ab}$ & $85.92 \mathrm{a}-\mathrm{c}$ & 88.15 \\
\hline & 150 & $81.17 \mathrm{~b}$ & $83.07 \mathrm{ab}$ & $302.54 \mathrm{~b}$ & $330.00 \mathrm{a}$ & $87.49 \mathrm{ab}$ & 85.57 \\
\hline \multirow{4}{*}{$7 \mathrm{~d}$} & 0 & $69.88 \mathrm{f}$ & $70.73 \mathrm{~d}$ & $185.03 \mathrm{f}$ & $203.67 \mathrm{e}$ & $81.62 \mathrm{a}-\mathrm{c}$ & 84.34 \\
\hline & 100 & $74.83 \mathrm{de}$ & $78.51 \mathrm{a}-\mathrm{c}$ & $233.94 \mathrm{de}$ & $263.33 \mathrm{c}-\mathrm{e}$ & $88.30 \mathrm{a}$ & 85.23 \\
\hline & 125 & $76.48 \mathrm{~cd}$ & $79.30 \mathrm{a}-\mathrm{c}$ & $239.06 \mathrm{~d}$ & $302.33 \mathrm{a}-\mathrm{d}$ & $85.30 \mathrm{a}-\mathrm{c}$ & 87.76 \\
\hline & 150 & $81.80 \mathrm{~b}$ & $77.40 \mathrm{~b}-\mathrm{d}$ & $293.95 \mathrm{~b}$ & $265.67 \mathrm{~b}-\mathrm{e}$ & $84.45 \mathrm{a}-\mathrm{c}$ & 86.54 \\
\hline \multicolumn{8}{|l|}{ Time } \\
\hline 30 & & 74.97 & 79.21 & 231.30 & 278.29 & 85.25 & 88.13 \\
\hline 21 & & 79.69 & 81.15 & 294.83 & 308.17 & 84.73 & 86.89 \\
\hline \multirow[t]{6}{*}{7} & & 75.74 & 76.48 & 237.99 & 258.75 & 84.92 & 85.97 \\
\hline & AVG concentrations & & & & & & \\
\hline & 0 & 70.40 & 72.48 & 189.09 & 223.67 & 78.81 & $84.45 \mathrm{~b}$ \\
\hline & 100 & 79.69 & 82.06 & 293.65 & 304.50 & 86.38 & $87.74 \mathrm{a}$ \\
\hline & 125 & 78.11 & 82.04 & 264.84 & 314.33 & 85.85 & $88.39 \mathrm{a}$ \\
\hline & 150 & 79.00 & 79.21 & 271.24 & 284.44 & 86.15 & $87.41 \mathrm{a}$ \\
\hline \multicolumn{8}{|l|}{$P$ values } \\
\hline Time $(\mathrm{T})$ & & 0.045 & 0.117 & 0.008 & 0.054 & 0.832 & 0.225 \\
\hline Concentrations (C) & & 0.000 & 0.000 & 0.000 & 0.000 & 0.006 & 0.030 \\
\hline $\mathrm{T} \times \mathrm{C}$ & & 0.000 & 0.001 & 0.000 & 0.000 & 0.000 & 0.108 \\
\hline
\end{tabular}

${ }^{1}$, days before harvest $(\mathrm{DBH})$; in each column, values followed by the same letter are not significantly different at $\mathrm{P} \leq 0.05$ level according to Duncan's multiple range test 
under shelf life conditions and cold storing them protect their hardness more effectively than the control group fruits. As a kind of flavoured pear, 'Williams' directly takes place both in domestic and foreign market. Hence a portion of shelf life is consumed during transport. In accordance with the data obtained from this study, it is probable that increase in fruit firmness may have favourable impact on shelf life of fruits, thus reducing effects of loss of quality during transportation.

Soluble solid content (SSC) and titratable acidity (TA): In both years, AVG concentrations $\times$ application time interaction on the SSC and TA in was found to be statistically significant $(\mathrm{P} \leq 0.05)$ (Table 3 ). In the first year, compared to only $21 \mathrm{DBH}-\mathrm{AVG}$ treated fruits showed lower values of SSC, while in the second year all AVG applications determined the same effect. In both years, AVG treatments had unstable effects on TA (Table 3). The effect was reported as variable depending on concentration of AVG application, time of application, variety and environmental conditions (Bramlage et al 1980). AVG applications reduced the SSC amount, however, no effect has been detected at quinic and malic acid amount (Drake et al 2005). Furthermore, Clayton et al (2000) reported that AVG applications

Table 3- The effect of AVG treatments total soluble solids (SSC) and titratable acidity (TA) in 'Williams' pear, 2011 and 2012

Çizelge 3- AVG uygulamalarının 'Williams' armudunda suda çözünebilir kuru madde (SÇKM) ve titre edilebilir asitliğe (TA) etkisi, 2011 ve 2012

\begin{tabular}{|c|c|c|c|c|c|}
\hline \multirow{2}{*}{ Application time ${ }^{I}$} & \multirow{2}{*}{$\begin{array}{l}\text { AVG concentrations } \\
\left(m g L^{-1}\right)\end{array}$} & \multicolumn{2}{|c|}{$S S C(\%)$} & \multicolumn{2}{|c|}{$T A(\%)$} \\
\hline & & 2011 & 2012 & 2011 & 2012 \\
\hline \multirow{4}{*}{$30 \mathrm{~d}$} & 0 & $14.40 \mathrm{c}$ & $16.90 \mathrm{a}$ & $0.45 \mathrm{c}-\mathrm{e}$ & $0.62 \mathrm{a}$ \\
\hline & 100 & $15.57 \mathrm{a}$ & $13.30 \mathrm{~cd}$ & $0.49 \mathrm{a}-\mathrm{d}$ & $0.42 \mathrm{~cd}$ \\
\hline & 125 & $15.03 \mathrm{a}-\mathrm{c}$ & $12.83 \mathrm{~d}$ & $0.42 \mathrm{de}$ & $0.48 \mathrm{~b}-\mathrm{d}$ \\
\hline & 150 & $15.93 \mathrm{a}$ & $15.43 \mathrm{ab}$ & $0.40 \mathrm{e}$ & $0.63 \mathrm{a}$ \\
\hline \multirow{4}{*}{$21 \mathrm{~d}$} & 0 & $15.30 \mathrm{a}-\mathrm{c}$ & $14.93 \mathrm{bc}$ & $0.48 \mathrm{a}-\mathrm{d}$ & $0.59 \mathrm{ab}$ \\
\hline & 100 & $14.50 \mathrm{bc}$ & $14.37 \mathrm{~b}-\mathrm{d}$ & $0.44 \mathrm{c}-\mathrm{e}$ & $0.49 \mathrm{~b}-\mathrm{d}$ \\
\hline & 125 & $14.93 \mathrm{a}-\mathrm{c}$ & $13.00 \mathrm{c}$ & $0.55 \mathrm{a}$ & $0.41 \mathrm{~d}$ \\
\hline & 150 & $15.30 \mathrm{a}-\mathrm{c}$ & $14.07 \mathrm{~b}-\mathrm{d}$ & $0.55 \mathrm{ab}$ & $0.54 \mathrm{a}-\mathrm{c}$ \\
\hline \multirow{4}{*}{$7 d$} & 0 & $14.37 \mathrm{c}$ & $15.23 \mathrm{ab}$ & $0.44 \mathrm{c}-\mathrm{e}$ & $0.59 \mathrm{ab}$ \\
\hline & 100 & $15.43 \mathrm{ab}$ & $13.97 \mathrm{~b}-\mathrm{d}$ & $0.47 \mathrm{~b}-\mathrm{d}$ & $0.51 \mathrm{a}-\mathrm{d}$ \\
\hline & 125 & $15.27 \mathrm{a}-\mathrm{c}$ & $13.03 \mathrm{~cd}$ & $0.38 \mathrm{e}$ & $0.51 \mathrm{a}-\mathrm{d}$ \\
\hline & 150 & $15.27 \mathrm{a}-\mathrm{c}$ & $14.60 \mathrm{~b}-\mathrm{d}$ & $0.51 \mathrm{a}-\mathrm{c}$ & $0.60 \mathrm{ab}$ \\
\hline \multicolumn{6}{|l|}{ Time } \\
\hline 30 & & 15.23 & 14.62 & 0.44 & 0.54 \\
\hline 21 & & 15.01 & 14.09 & 0.50 & 0.51 \\
\hline \multirow[t]{6}{*}{7} & & 15.08 & 14.21 & 0.45 & 0.55 \\
\hline & AVG concentrations & & & & \\
\hline & 0 & 14.69 & 15.69 & 0.46 & 0.60 \\
\hline & 100 & 15.17 & 13.88 & 0.47 & 0.47 \\
\hline & 125 & 15.08 & 12.96 & 0.45 & 0.47 \\
\hline & 150 & 15.50 & 14.70 & 0.49 & 0.59 \\
\hline \multicolumn{6}{|l|}{$P$ values } \\
\hline Time $(\mathrm{T})$ & & 0.695 & 0.654 & 0.016 & 0.467 \\
\hline Concentrations (C) & & 0.056 & 0.000 & 0.697 & 0.000 \\
\hline $\mathrm{T} \times \mathrm{C}$ & & 0.029 & 0.000 & 0.000 & 0.003 \\
\hline
\end{tabular}

1, days before harvest (DBH); in each column, values followed by the same letter are not significantly different at $\mathrm{P} \leq 0.05$ level according to Duncan's multiple range tests 
increase SSC amount and reduce the amount of TA, which has also been observed in our results.

Fruit colours: AVG concentrations $\times$ application times interaction on the fruit colour component $L^{*}, b^{*}$ and $\mathrm{C}^{*}$ values was found to be statistically significant $(\mathrm{P} \leq 0.05)$. AVG concentrations on the $\mathrm{h}^{\circ}$ values in was found to be statistically significant $(\mathrm{P} \leq 0.05)$. AVG treatments had no significant influenced on $a^{*}$ values (Table 4 ). $L^{*}$ values decreased with AVG treatments. The highest $\mathrm{L}^{*}$ value was observed in control fruit groups. The AVG applications increased $b^{*}$ value (yellowness). AVG effected on late ripening and also on late colouration of fruits, for this reason in our study $b^{*}$ value increased. The highest $C^{*}$ value (49.33) was determined in $30 \mathrm{DBH}-100 \mathrm{mg} \mathrm{L}^{-1} \mathrm{AVG}$ fruits. The only AVG concentrations reduced $h^{\circ}$ values (Table 4). However, all AVG concentrations were included same group in statistics. The effect of AVG applications on fruit coloration resulted differently in several studies. The colouration was delayed for 'Redfree', 'Gala' and 'Golden Delicious' varieties with AVG applications, while red colour was not affected in 'Rome' variety. Greene (2006) stated that decrease in red color is correlated with delay in maturation rather than the prevention of red color development.

Table 4- The effect of AVG treatments fruit colour $\left(L^{*}, a^{*}, b^{*}, C^{*}\right.$ and $\left.h^{\circ}\right)$ in 'Williams' pear (2011 and 2012 means)

Çizelge 4- AVG uygulamalarinin 'Williams' armudunda meyve rengine ( $L^{*}, a^{*}, b^{*}, C^{*}$ and $\left.h^{\circ}\right)$ etkisi (2011 ve 2012 ortalamalarl)

\begin{tabular}{|c|c|c|c|c|c|c|}
\hline \multirow{2}{*}{ Application time ${ }^{I}$} & \multirow{2}{*}{$\begin{array}{l}\text { AVG concentrations } \\
\left(m g L^{-1}\right)\end{array}$} & \multicolumn{5}{|c|}{ Fruit colour } \\
\hline & & $L^{*}$ & $a^{*}$ & $b^{*}$ & $C^{*}$ & $h^{\circ}$ \\
\hline \multirow{4}{*}{$30 \mathrm{~d}$} & 0 & $68.45 \mathrm{a}$ & -10.23 & $45.04 \mathrm{a}-\mathrm{d}$ & $46.99 \mathrm{~b}-\mathrm{d}$ & 101.90 \\
\hline & 100 & $65.50 \mathrm{bc}$ & -11.13 & $47.14 \mathrm{a}$ & $49.33 \mathrm{a}$ & 102.21 \\
\hline & 125 & $64.05 \mathrm{c}$ & -10.40 & $46.02 \mathrm{a}-\mathrm{c}$ & 48.34 a-c & 101.22 \\
\hline & 150 & $64.17 \mathrm{c}$ & -8.12 & $46.18 \mathrm{a}-\mathrm{c}$ & $48.08 \mathrm{a}-\mathrm{c}$ & 98.54 \\
\hline \multirow{4}{*}{$21 \mathrm{~d}$} & 0 & $68.43 \mathrm{a}$ & -9.93 & $45.34 \mathrm{a}-\mathrm{d}$ & $47.05 \mathrm{~b}-\mathrm{d}$ & 100.93 \\
\hline & 100 & $63.59 \mathrm{c}$ & -10.62 & $46.60 \mathrm{ab}$ & $49.13 \mathrm{ab}$ & 101.20 \\
\hline & 125 & $62.88 \mathrm{c}$ & -8.87 & $45.74 \mathrm{a}-\mathrm{c}$ & $48.57 \mathrm{a}-\mathrm{c}$ & 98.65 \\
\hline & 150 & $64.72 \mathrm{c}$ & -9.02 & $46.35 \mathrm{a}-\mathrm{c}$ & $48.96 \mathrm{ab}$ & 99.09 \\
\hline \multirow{4}{*}{$7 \mathrm{~d}$} & 0 & $67.86 \mathrm{ab}$ & -9.41 & $45.02 \mathrm{a}-\mathrm{d}$ & $46.52 \mathrm{~cd}$ & 100.93 \\
\hline & 100 & $63.27 \mathrm{c}$ & -7.56 & $46.63 \mathrm{~b}-\mathrm{d}$ & $47.01 \mathrm{~b}-\mathrm{d}$ & 97.34 \\
\hline & 125 & $63.03 \mathrm{c}$ & -9.60 & $44.12 \mathrm{~cd}$ & $46.83 \mathrm{~b}-\mathrm{d}$ & 100.11 \\
\hline & 150 & $62.49 \mathrm{c}$ & -5.43 & $43.25 \mathrm{~d}$ & $45.31 \mathrm{~d}$ & 95.29 \\
\hline \multicolumn{7}{|l|}{ Time } \\
\hline 30 & & 65.54 & -9.96 & 46.10 & 46.42 & 100.97 \\
\hline 21 & & 64.91 & -9.61 & 46.01 & 48.43 & 100.14 \\
\hline \multirow[t]{6}{*}{7} & & 64.16 & -8.00 & 44.26 & 48.18 & 98.42 \\
\hline & AVG concentrations & & & & & \\
\hline & 0 & 68.25 & 9.85 & 45.13 & 46.85 & $101.48 \mathrm{a}$ \\
\hline & 100 & 64.12 & 9.77 & 46.12 & 48.49 & $100.25 \mathrm{ab}$ \\
\hline & 125 & 63.32 & 9.62 & 45.29 & 47.91 & $99.9 \mathrm{a} b$ \\
\hline & 150 & 63.79 & 7.52 & 45.26 & 47.45 & $97.64 \mathrm{~b}$ \\
\hline \multicolumn{7}{|l|}{$P$ values } \\
\hline Time $(\mathrm{T})$ & & 0.275 & 0.076 & 0.000 & 0.000 & 0.094 \\
\hline Concentrations (C) & & 0.000 & 0.085 & 0.386 & 0.079 & 0.041 \\
\hline $\mathrm{T} \times \mathrm{C}$ & & 0.000 & 0.133 & 0.011 & 0.002 & 0.094 \\
\hline
\end{tabular}

${ }^{1}$, days before harvest $(\mathrm{DBH})$; in each column, values followed by the same letter are not significantly different at $\mathrm{P} \leq 0.05$ level according to Duncan's multiple range test 


\subsection{Ethylene production and respiration rates}

As showed in Table 5, ethylene production rate was influenced significantly $(\mathrm{P} \leq 0.05)$ by $\mathrm{AVG}$ applications in 2011 and 2012. In the first year, the ethylene production of all application time in control group fruits illustrated the highest value $\left(5.46 \mu \mathrm{L} \mathrm{kg}^{-1} \mathrm{~h}^{-1}, 4.05 \mu \mathrm{L} \mathrm{kg}^{-1} \mathrm{~h}^{-1}\right.$ and $3.63 \mu \mathrm{L} \mathrm{kg}^{-1}$ $\mathrm{h}^{-1}$, respectively) while $30 \mathrm{DBH}-100 \mathrm{mg} \mathrm{L}^{-1} \mathrm{AVG}$ fruits had the lowest value $\left(0.22 \mu \mathrm{L} \mathrm{kg}^{-1} \mathrm{~h}^{-1}\right)$. In the second experiment year, all of the control groups determined ethylene production. In 2011, AVG concentrations $\times$ application time interaction on the fruit respiration rates were found to be statistically significant $(\mathrm{P} \leq 0.05)$. In 2012, respiration rates of fruits were influenced significantly by AVG concentrations $(\mathrm{P} \leq 0.05)$. All the AVG-treated fruits showed the lowest respirations rates in 2011 and 2012. Besides all AVG applications were included in the same group in statistics (Table 5). Similar to our findings, Clayton et al (2000) and Bregoli et al (2002) stated that AVG decreases the amount of ethylene and the respiration rate of 'Bartlett' pear, 'Jersey Mac' apple, 'Red Haven' peach, respectively. They also specified that the application doses showed similar impact.

Table 5- The effect of AVG treatments on ethylene production rate and respiration rate in 'Williams' pear, 2011 and 2012

Çizelge 5- AVG uygulamalarının 'Williams'armudunda etilen üretimi ve solunum hızına etkisi, 2011 ve 2012

\begin{tabular}{|c|c|c|c|c|c|}
\hline \multirow[t]{2}{*}{ Application time $e^{I}$} & \multirow{2}{*}{$\begin{array}{l}\text { AVG concentrations } \\
\left(m g L^{-1}\right)\end{array}$} & \multicolumn{2}{|c|}{$\begin{array}{c}\text { Ethylene production } \\
\left(\mu L \mathrm{~kg}^{-1} h^{-1}\right)\end{array}$} & \multicolumn{2}{|c|}{$\begin{array}{l}\text { Respiration rate } \\
\quad\left(\mu L \mathrm{~kg}^{-1} h^{-1}\right)\end{array}$} \\
\hline & & 2011 & 2012 & 2011 & 2012 \\
\hline \multirow{4}{*}{$30 \mathrm{~d}$} & 0 & $3.63 \mathrm{a}$ & $4.00 \mathrm{ab}$ & $42.99 \mathrm{~b}$ & 42.02 \\
\hline & 100 & $0.22 \mathrm{~b}$ & $0.00 \mathrm{c}$ & $6.20 \mathrm{c}$ & 1.99 \\
\hline & 125 & $0.35 \mathrm{~b}$ & $0.00 \mathrm{c}$ & $4.39 \mathrm{c}$ & 1.45 \\
\hline & 150 & $0.29 \mathrm{~b}$ & $0.00 \mathrm{c}$ & $6.81 \mathrm{c}$ & 1.76 \\
\hline \multirow{4}{*}{$21 \mathrm{~d}$} & 0 & $4.05 \mathrm{a}$ & $4.30 \mathrm{a}$ & $59.11 \mathrm{ab}$ & 51.68 \\
\hline & 100 & $0.27 \mathrm{~b}$ & $0.00 \mathrm{c}$ & $6.89 \mathrm{c}$ & 1.72 \\
\hline & 125 & $0.36 \mathrm{~b}$ & $0.00 \mathrm{c}$ & $8.14 \mathrm{c}$ & 1.59 \\
\hline & 150 & $0.53 \mathrm{~b}$ & $0.00 \mathrm{c}$ & $4.15 \mathrm{c}$ & 1.42 \\
\hline \multirow{4}{*}{$7 d$} & 0 & $5.46 \mathrm{a}$ & $2.70 \mathrm{~b}$ & $78.88 \mathrm{a}$ & 62.10 \\
\hline & 100 & $0.27 \mathrm{~b}$ & $0.00 \mathrm{c}$ & $5.49 \mathrm{c}$ & 1.74 \\
\hline & 125 & $0.30 \mathrm{~b}$ & $0.00 \mathrm{c}$ & $6.33 \mathrm{c}$ & 1.686 \\
\hline & 150 & $0.31 \mathrm{~b}$ & $0.00 \mathrm{c}$ & $5.20 \mathrm{c}$ & 1.51 \\
\hline \multicolumn{6}{|l|}{ Time } \\
\hline 30 & & 1.12 & 1.00 & 15.10 & 11.81 \\
\hline 21 & & 1.30 & 1.08 & 19.57 & 14.10 \\
\hline \multirow[t]{6}{*}{7} & & 1.58 & 0.68 & 23.97 & 16.76 \\
\hline & AVG concentrations & & & & \\
\hline & 0 & 4.38 & 3.66 & 60.33 & $51.93 \mathrm{a}$ \\
\hline & 100 & 0.25 & 0.00 & 6.19 & $1.82 \mathrm{ab}$ \\
\hline & 125 & 0.34 & 0.00 & 6.28 & $1.56 \mathrm{~b}$ \\
\hline & 150 & 0.38 & 0.00 & 5.39 & $1.57 \mathrm{~b}$ \\
\hline \multicolumn{6}{|l|}{$\mathrm{P}$ values } \\
\hline Time $(\mathrm{T})$ & & 0.860 & 0.840 & 0.755 & 0.220 \\
\hline Concentrations (C) & & 0.000 & 0.000 & 0.000 & 0.017 \\
\hline $\mathrm{T} \times \mathrm{C}$ & & 0.000 & 0.000 & 0.000 & 0.097 \\
\hline
\end{tabular}

${ }^{1}$, days before harvest (DBH); in each column, values followed by the same letter are not significantly different at $\mathrm{P} \leq 0.05$ level according to Duncan's multiple range test 


\subsection{Fruit mineral composition}

Effects of AVG applications on 'Williams' pear mineral composition were given in Table 6 and 7 (in 2011 and 2012 means). Interactive effects of AVG concentrations and application times on the calcium were $(\mathrm{P} \leq 0.05)$. Nitrogen and phosphorus were influenced significantly $(\mathrm{P} \leq 0.05)$ by $\mathrm{AVG}$ concentrations. The average nitrogen contents were $0.31-0.50 \%$ and phosphorus contents were determined between $0.088-0.110 \%$. Potassium and magnesium were not found statistically significant
$(\mathrm{P} \leq 0.05) \quad$ (Table 6). AVG treatments showed different effects on calcium contents. 30 DBH-125 $\mathrm{mg} \mathrm{L}^{-1}$ AVG-treated fruits and $30 \mathrm{DBH}-$ control fruits had the highest calcium $(0.083$ and $0.085 \%)$ contents (Table 6). Effects of AVG concentrations and application times on other mineral contents (iron, copper, manganese, zinc, boron) were not statistically significant (Table 7). Even though not many studies are done regarding the effect of AVG applications on micro and macro elements of fruits, Butar (2013) observed that AVG treatments

Table 6- The effect of AVG treatments on fruit mineral composition (nitrogen, phosphorus, potassium, calcium, magnesium) in 'Williams' pear (2011 and 2012 means)

Çizelge 6- AVG uygulamalarının 'Williams' armudunda meyvenin mineral içeriklerine (azot, fosfor, potasyum, kalsiyum, magnezyum) etkisi (2011 ve 2102 ortalamalarl)

\begin{tabular}{|c|c|c|c|c|c|c|}
\hline \multirow{2}{*}{ Application time $e^{I}$} & \multirow{2}{*}{$\begin{array}{l}\text { AVG concentrations } \\
\left(m g L^{-1}\right)\end{array}$} & Nitrogen & Phosphorus & Potassium & Calcium & Magnesium \\
\hline & & \multicolumn{5}{|c|}{$(\%)$} \\
\hline \multirow{4}{*}{$30 \mathrm{~d}$} & 0 & 0.31 & 0.091 & 0.81 & $0.085 \mathrm{a}$ & 0.057 \\
\hline & 100 & 0.41 & 0.110 & 0.86 & $0.064 \mathrm{~b}$ & 0.049 \\
\hline & 125 & 0.40 & 0.110 & 0.84 & $0.083 \mathrm{a}$ & 0.056 \\
\hline & 150 & 0.35 & 0.100 & 0.81 & $0.064 \mathrm{~b}$ & 0.049 \\
\hline \multirow{4}{*}{$21 \mathrm{~d}$} & 0 & 0.34 & 0.092 & 0.78 & $0.061 \mathrm{~b}$ & 0.052 \\
\hline & 100 & 0.39 & 0.100 & 0.78 & $0.062 \mathrm{~b}$ & 0.053 \\
\hline & 125 & 0.37 & 0.100 & 0.84 & $0.063 \mathrm{~b}$ & 0.053 \\
\hline & 150 & 0.32 & 0.100 & 0.81 & $0.068 \mathrm{ab}$ & 0.050 \\
\hline \multirow{4}{*}{$7 \mathrm{~d}$} & 0 & 0.31 & 0.088 & 0.75 & $0.067 \mathrm{ab}$ & 0.052 \\
\hline & 100 & 0.31 & 0.100 & 0.78 & $0.070 \mathrm{ab}$ & 0.052 \\
\hline & 125 & 0.50 & 0.100 & 0.88 & $0.059 \mathrm{~b}$ & 0.056 \\
\hline & 150 & 0.37 & 0.090 & 0.75 & $0.076 \mathrm{ab}$ & 0.052 \\
\hline \multicolumn{7}{|l|}{ Time } \\
\hline 30 & & 0.36 & 0.099 & 0.79 & 0.074 & 0.052 \\
\hline 21 & & 0.35 & 0.098 & 0.82 & 0.063 & 0.052 \\
\hline \multirow[t]{6}{*}{7} & & 0.38 & 0.095 & 0.80 & 0.068 & 0.053 \\
\hline & AVG concentrations & & & & & \\
\hline & 0 & $0.32 b$ & $0.090 \mathrm{~b}$ & 0.80 & 0.070 & 0.054 \\
\hline & 100 & $0.39 \mathrm{ab}$ & $0.100 \mathrm{a}$ & 0.82 & 0.060 & 0.051 \\
\hline & 125 & $0.42 \mathrm{a}$ & $0.100 \mathrm{a}$ & 0.83 & 0.070 & 0.055 \\
\hline & 150 & $0.35 \mathrm{ab}$ & $0.096 \mathrm{ab}$ & 0.77 & 0.070 & 0.050 \\
\hline \multicolumn{7}{|l|}{$P$ values } \\
\hline Time $(\mathrm{T})$ & & 0.201 & 0.555 & 0.377 & 0.051 & 0.862 \\
\hline Concentrations (C) & & 0.031 & 0.030 & 0.198 & 0.771 & 0.124 \\
\hline $\mathrm{T} \times \mathrm{C}$ & & 0.201 & 0.354 & 0.485 & 0.026 & 0.462 \\
\hline
\end{tabular}

${ }^{1}$, days before harvest $(\mathrm{DBH})$; in each column, values followed by the same letter are not significantly different at $\mathrm{P} \leq 0.05$ level according to Duncan's multiple range test 
affect nitrogen, manganese and iron contents and this effect was noticeably seen in $150 \mathrm{mg} \mathrm{L}^{-1} \mathrm{AVG}$ treatment of 'Jersey Mac' apple. At the end of 3 days shelf life, and $500 \mathrm{mg} \mathrm{L}^{-1}$ and $1000 \mathrm{mg} \mathrm{L}^{-1}$ doses of after-harvest AVG-applied 'Fuji' and 'Granny Smith' apples, nitrogen amount was found to reduce in 'Granny Smith' variety, while increase at $500 \mathrm{mg}$ $\mathrm{L}^{-1}$ AVG application and decrease at $1000 \mathrm{mg} \mathrm{L}^{-1}$ AVG application on 'Fuji' apple. On the other side, it was determined that $\mathrm{Ca}$ amount increases with $\mathrm{AVG}$ treatments of 'Fuji', Mg amount increases only after $500 \mathrm{mg} \mathrm{L}^{-1}$ treatment and both $\mathrm{Ca}$ and $\mathrm{Mg}$ amounts increase only after $1000 \mathrm{mg} \mathrm{L}^{-1}$ AVG application on 'Granny Smith' variety (Fadhil 2007). Karaçalı (2009) stated that pre harvest drop may occur if the phosphorus level decreases and a fruit with high

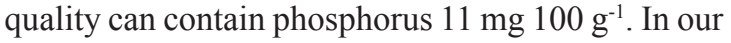
study AVG treatments increased phosphorus levels

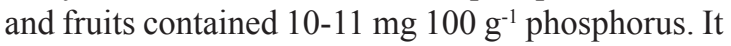
was identified that AVG applications have an effect on the macro elements of fruit. AVG concentrations increased nitrogen contents from $32 \%$ to $38 \%$ on average and phosphorus contents from $0.090 \%$ to $0.099 \%$ on average. Referring to the micro elements of fruits, AVG applications were not found to be effective on micro elements.

Table 7- The effect of AVG treatments on fruit mineral composition (Iron, copper, manganese, zinc, boron) in 'Williams' pear (2011 and 2012 means)

Çizelge 7- AVG uygulamalarının 'Williams' armudunda meyvenin mineral içeriklerine (demir, bakır, mangan, çinko, bor) etkisi (2011 ve 2012 ortalamalarl)

\begin{tabular}{|c|c|c|c|c|c|c|}
\hline \multirow{2}{*}{ Application time $e^{I}$} & \multirow{2}{*}{$\begin{array}{l}\text { AVG concentrations } \\
\left(m g L^{-1}\right)\end{array}$} & Iron & Copper & Manganese & Zinc & Boron \\
\hline & & \multicolumn{5}{|c|}{$\left(m g k g^{-1}\right)$} \\
\hline \multirow{4}{*}{$30 \mathrm{~d}$} & 0 & 12.74 & 8.48 & 3.51 & 8.56 & 14.43 \\
\hline & 100 & 12.76 & 8.75 & 2.71 & 8.57 & 12.36 \\
\hline & 125 & 11.87 & 8.58 & 3.00 & 8.80 & 13.49 \\
\hline & 150 & 12.13 & 8.64 & 2.48 & 7.86 & 11.74 \\
\hline \multirow{4}{*}{$21 \mathrm{~d}$} & 0 & 11.50 & 9.28 & 2.70 & 8.38 & 14.54 \\
\hline & 100 & 16.38 & 8.43 & 2.89 & 8.47 & 14.14 \\
\hline & 125 & 13.53 & 9.04 & 2.97 & 8.69 & 13.89 \\
\hline & 150 & 12.22 & 9.62 & 3.18 & 9.34 & 15.15 \\
\hline \multirow{4}{*}{$7 d$} & 0 & 12.02 & 8.64 & 3.08 & 8.30 & 13.93 \\
\hline & 100 & 13.31 & 9.34 & 3.34 & 9.64 & 14.87 \\
\hline & 125 & 11.89 & 9.91 & 3.36 & 9.43 & 14.11 \\
\hline & 150 & 12.57 & 9.23 & 3.07 & 8.07 & 14.67 \\
\hline \multicolumn{7}{|l|}{ Time } \\
\hline 30 & & 12.06 & 8.61 & 2.92 & 8.45 & 13.00 \\
\hline 21 & & 13.88 & 9.09 & 2.94 & 8.72 & 14.45 \\
\hline \multirow[t]{6}{*}{7} & & 12.45 & 9.28 & 3.21 & 9.11 & 14.35 \\
\hline & AVG concentrations & & & & & \\
\hline & 0 & 12.71 & 8.80 & 3.10 & 8.41 & 14.30 \\
\hline & 100 & 13.85 & 8.84 & 2.98 & 8.87 & 13.79 \\
\hline & 125 & 12.52 & 9.17 & 3.11 & 8.97 & 13.86 \\
\hline & 150 & 12.12 & 9.16 & 2.91 & 8.76 & 13.85 \\
\hline \multicolumn{7}{|l|}{$P$ values } \\
\hline Time $(\mathrm{T})$ & & 0.149 & 0.147 & 0.539 & 0.581 & 0.083 \\
\hline Concentrations (C) & & 0.467 & 0.689 & 0.923 & 0.882 & 0.931 \\
\hline $\mathrm{T} \times \mathrm{C}$ & & 0.582 & 0.516 & 0.900 & 0.983 & 0.533 \\
\hline
\end{tabular}

${ }^{1}$, days before harvest $(\mathrm{DBH})$; in each column, values followed by the same letter are not significantly different at $\mathrm{P} \leq 0.05$ level according to Duncan's multiple range test 


\section{Conclusions}

Considering all results together, in respect to preharvest fruit drop and fruit quality, AVG applications were found to be significant for 'Williams' pear and, the most significant application time and doses were considered to be $100 \mathrm{mg} \mathrm{L}^{-1}$ treatment 30 and 21 days before the estimated harvest. High AVG treatment concentrations were used in the study. They were effective also for fruit quality but low AVG concentrations can be advised for human health and environmental conditions.

\section{Acknowledgements}

This study was supported by the General Directorate of Agricultural Researches and Policies (Project: TAGEM/BBAD/12/A08/P01/02). The plant materials and 'ValentBioScience Company' for supporting the $\operatorname{ReTain}^{\circledR}$.

\section{References}

Amarante C V T do, Drehmer A M F, Souza F de \& Francescatto P (2005). Preharvest spraying with gibberellic acid $\left(\mathrm{GA}_{3}\right)$ and aminoethoxyvinylglycine $(\mathrm{AVG})$ delays fruit maturity and reduces fruit losses on peaches. Revista Brasilerie de Fruticultura 27(1): $1-5$

Andreotti C, Bregoli A M \& Costa G (2004). Pre- and postharvest aminoethoxyvinylglycine (AVG) application affects maturity and storage of pear fruit. European Journal of Horticultural Science 69(4): 147-152

Bramlage W J, Greene D W, Autio W R \& McLaughlin J M (1980). Effects of aminoethoxyvinylglycine on internal ethylene concentrations and storage of apples. Journal of the American Society for Horticultural Science 105: 847-851

Bregoli A M, Scaramagli S, Costa G, Sabatini E, Ziosi V, Biondi S \& Torrigiani P (2002). Peach (Prunus persica) fruit ripening: Aminoethoxyvinylglycine $(\mathrm{AVG})$ and exogenous polyamines affect ethylene emission and flesh firmness. Physiologia Plantarum 114: $472-481$

Butar S (2013). AVG (aminoethoxyvinilglycine)'nin 'Jersey Mac' elma çeşidinde hasat önü meyve dökümü, hasat zamanı ve meyve kalitesi üzerine etkileri. Yüksek lisans tezi, Adnan Menderes Üniversitesi Fen Bilimleri Enstitüsü (Basılmamış), Aydın
Clayton M, Biasi W V, Southwick S M \& Mitcham E J (2000). ReTain affects maturity and ripening of 'Bartlett' pear. HortScience 35(7): 1294-1299

Çetinbaş M \& Koyuncu F (2011). Effects of aminoethoxyvinylglycine on harvest time and fruit quality of 'Monroe' peaches. Tartm Bilimleri DergisiJournal of Agricultural Sciences 17: 177-189

Çetinbaş M, Butar S, Onursal C E \& Koyuncu M A (2012). The effects of pre-harvest ReTain [aminoethoxyvinylglycine (AVG)] application on quality change of 'Monroe' peach during normal and controlled atmosphere storage. Scientia Horticulturae 147: $1-7$

Drake S R, Eisele T A, Elfving D C, Drake M A, Drake S L \& Visser D B (2005). Effects of the bioregulators aminoethoxyvinylglycine and etephon on SSC, carbonhydrate, acid, and mineral concentrations in 'Scarletspur Delicious' apple juice. HortScience 40(5): 1421-1424

Fadhil N N (2007). Relationship between fruit content of $\mathrm{N}, \mathrm{Ca}$ and $\mathrm{Mg}$ and physiological disorders of apples cvs. Fuji and Granny Smith. $8^{\text {th }}$ African Crop Science Conference Proceedings, 27-31 October, El-Minia, Egypt, pp. 407-409

Greene D W (2006). An update on preharvest drop control of apples with aminoethoxyvinylglycine (ReTain). Acta Horticulturae 727: 311-320

Gunes G, Watkins C B \& Hotchkiss J H (2001). Physiological responses of fresh-cut apple slices under high $\mathrm{CO}_{2}$ and low $\mathrm{O}_{2}$ partial pressures. Postharvest Biology and Technology 22: 197-204

Kang I K, Byun J K, Kweon H J, Kim M J, Kwon S, Park M Y, Lee D H, Choi C \& Choi D G (2007). Effects of aminoethoxyvinylglycine on preharvest drop, fruit color, and quality of 'Tsugaru' apples. Horticulture, Environment and Biotechnology 48(3): 159-164

Karaçalı I (2009). Bahçe Ürünlerinin Muhafazası ve Pazarlamas1. Ege Üniversitesi Ziraat Fakültesi Yayınları: 494, Ders Kitab1: 444, İzmir

Kim I S, Choi C D, Lee H J \& Byun J K (2004). Effects of aminoethoxyvinylglycine on preharvest drop and fruit quality of 'Mibaekdo' peaches. Acta Horticulturae 653: $173-178$

Petri J L, Leite G B, Argenta L C \& Basso C (2006). Ripening delay and fruit drop control in 'Imperial Gala' and 'Suprema' ('Fuji' sport) apples by applying AVG (aminoethoxyvinylglycine). Acta Horticulturae 727: 519-524 
Phan-Thien K Y, Wargo J M, Mitchell L W, Collett M G \& Rath A C (2004). Delay in ripening of Gala and Pink Lady apples in commercial orchards following pre-harvest applications of aminoethoxyvinylglycine. Australian Journal of Experimental Agriculture 44: 807-812

Rath A C \& Prentice A J (2004). Yield increase and higher flesh firmness of 'Arctic Snow' nectaries both at harvest in Australia and after export to Taiwan following pre-harvest application of retain plant growth regulator (aminoethoxyvinylglycine, AVG). Australian Journal of Experimental Agriculture 44: 343-351

Rath A C, Kang I, Park C, Yoo W \& Byun J (2006). Foliar application of aminoethoxyvinylglycine (AVG) delays fruit ripening and reduces pre-harvest fruit drop and ethylene production of bagged 'Kogetsu' apples. Plant Growth Regulation 50: 91-100

Romani R, Labavitch J, Yamashita T, Hess B \& Rae H (1983). Preharvest AVG treatment of 'Bartlett' pear fruits: Effects on ripening, color change, and volatiles. Journal of the American Society for Horticultural Science 108(6): 1046-1049

Schupp J R \& Greene D W (2004). Effect of aminoethoxyvinylglycine (AVG) on preharvest drop, fruit quality, and maturation of 'McIntosh' apples. I. Concentration and timing of dilute applications of AVG. HortScience 39: 1030-1035

Venburg G D, Hopkins R \& Retamales J (2008). Recent developments in AVG research. Acta Horticulturae 796: 43-49

Wang Z \& Dilley D R (2001). Aminoethoxyvinylglycine, combined with ethephon, can enhance red color development without over-ripening apples. HortScience 36: 328-331

Whale S K, Singh Z, Behboudian M H, Janes J \& Dhaliwal S S (2008). Fruit quality in 'Cripp's Pink' apple, especially colour, as affected by preharvest sprays of aminoethoxyvinlglycine and ethephon. Scientia Horticulturae 115: 342-351

WookJae Y, InKyu K, HunJoong K, MokJong K, DaeHyun K, DongHun L \& JaeKyun B (2006). Usage potentiality of starch pattern index at aminoethoxyvinylglycine treatment to prevent preharvest drop in 'Tsugaru' apple fruits. Korean Journal of Horticultural Science Technology 24(1): 64-69

Yang S F, Hoffman N E, Mckeon T, Riov J, Jao C H \& Yung K H (1982). Effects of preharvest applications of AVG on ripening of 'Bartlett' pears with and without cold storage. HortScience 17: 214-215 